\title{
STRUCTURAL CHARACTERIZATION AND ANTIMICROBIAL ACTIVITY OF A SILVER(I) COMPLEX OF ARGININE
}

\author{
S. Ahmad ${ }^{1}$, A. Yousaf ${ }^{1}$, M.N. Tahir ${ }^{2}$, A.A. Isab ${ }^{3}$, M. Monim-ul-Mehboob ${ }^{3}$, \\ W. Linert ${ }^{4}$, M. Saleem ${ }^{5}$ \\ ${ }^{1}$ Department of Chemistry, University of Engineering and Technology, Lahore 54890, Pakistan \\ E-mail: saeed_a786@hotmail.com \\ ${ }^{2}$ Department of Physics, University of Sargodha, Sargodha, Pakistan \\ ${ }^{3}$ Department of Chemistry, King Fahd University of Petroleum and Minerals, Dhahran 31261, Saudi Arabia \\ ${ }^{4}$ Institute of Applied Synthetic Chemistry, Vienna University of Technology, A-1060 Vienna, Austria \\ ${ }^{5}$ Department of Civil Engineering, Jubail University College, P. O. Box 10074, Jubail Industrial City 31961, Saudi \\ Arabia
}

Received September, 7, 2014

\begin{abstract}
A silver(I) complex of arginine ( $\arg ),[\mathrm{Ag}(\arg )] \mathrm{NO}_{3} \cdot 0.5 \mathrm{H}_{2} \mathrm{O}(\mathbf{1})$ was prepared and characterized by elemental analysis, IR and NMR spectroscopy, and X-ray crystallography. The IR and NMR spectroscopic data confirmed the coordination of the ligand to silver(I). The structure of 1 shows that it is polymeric with each silver atom bound to the carboxyl $\mathrm{O}$ atom of one arginine ligand and to the amino $\mathrm{N}$ atom of another adopting a linear coordination environment. The two coordinate $\mathrm{N}-\mathrm{Ag}-\mathrm{O}$ units are repeated to form infinite chains. The molecular structure is stabilized by $\mathrm{N}-\mathrm{H}$... $\mathrm{O}$ and $\mathrm{C}-\mathrm{H}$... O hydrogen bonds. Antimicrobial activities of the complex were evaluated by minimum inhibitory concentration against gram-negative bacteria (E. coli, P. aeruginosa), molds (A. niger, P. citrinum) and yeasts (C. albicans, S. cerevisiae).
\end{abstract}

DOI: $10.15372 / \mathrm{JSC} 20150830$

K e y w o r d s: synthesis, silver nitrate, amino acids, arginine, crystal structure.

\section{INTRODUCTION}

Silver(I) complexes of amino acids have attracted considerable interest because of their wide ranging antimicrobial properties and a variety of binding modes [ $1-6]$. It has been suggested that ligand-exchangeability plays a key role in a wide spectrum of the antimicrobial activities of silver(I) complexes [ $1-5,7]$. Although most of active complexes have $\mathrm{Ag}-\mathrm{O}$ bonds, some labile $\mathrm{Ag}-\mathrm{N}$ complexes also exhibit effective antimicrobial activities against microorganisms [8,9]. The $\mathrm{Ag}-\mathrm{O}$ bonding complexes can readily undergo ligand replacement with sulfur containing biological ligands such as proteins [ $1-5]$. The structural reports reveal that the silver(I) complexes of amino acids usually exist in the form of polymers [ $2-4,10-12$ ]. The bonding modes of the silver(I) centers in these complexes have been classified into three types; those having only $\mathrm{Ag}-\mathrm{O}$ bonds, those having both $\mathrm{Ag}-\mathrm{O}$ and $\mathrm{Ag}-\mathrm{N}$ bonds and those having only $\mathrm{Ag}-\mathrm{N}$ bonds [ $2-4]$. These coordination modes are associated with the chelating, monodentate and bridging forms of the amino acids. In order to investigate further about silver(I) binding to amino acids, we report here the crystal structure and antimicrobial activities of a new polymeric silver(I) complex of arginine, $\left\{[\mathrm{Ag}(\arg )] \mathrm{NO}_{3} \cdot 0.5 \mathrm{H}_{2} \mathrm{O}\right\}_{n}(\mathbf{1})$, which is stabilized through hydrogen bonding and argentophilic interactions.

(C) Ahmad S., Yousaf A., Tahir M.N., Isab A.A., Monim-ul-Mehboob M., Linert W., Saleem M., 2015 


\section{EXPERIMENTAL}

Synthesis of $[\mathbf{A g}(\mathbf{a r g})]\left(\mathrm{NO}_{3}\right) \cdot \mathbf{0 . 5} \mathbf{H}_{2} \mathrm{O}$ (1). To a clear solution of $0.17 \mathrm{~g}(1.0 \mathrm{mmol}) \mathrm{AgNO}_{3}$ (Merck Product) in $10 \mathrm{~mL}$ of acetonitrile was added a solution of $0.17 \mathrm{~g}(1.0 \mathrm{mmol})$ arginine (Fluka) in $10 \mathrm{~mL}$ of water under stirring. During half an hour no change in color was observed in the colorless turbid solution. The turbidity was filtered off and the clear filtrate was allowed to stand for crystallization. After three days, colorless needle crystals were obtained, which were washed with acetonitrile and dried (M.p. $=202-204{ }^{\circ} \mathrm{C}$ ).

IR and NMR measurements. The IR spectra were recorded on a Perkin-Elmer FTIR 180 spectrophotometer in $\mathrm{KBr}$ pellets over the range $4000-400 \mathrm{~cm}^{-1}$. The ${ }^{1} \mathrm{H}$ NMR spectra of the ligand and complex in DMSO- $d_{6}$ were obtained on a Jeol JNM-LA 500 NMR spectrometer operating at a frequency of $500.00 \mathrm{MHz}$ at $297 \mathrm{~K}$ in $0.10 \mathrm{M}$ solution. The ${ }^{13} \mathrm{C}$ NMR spectra were obtained at the frequency of $125.65 \mathrm{MHz}$ with ${ }^{1} \mathrm{H}$ broadband decoupling at $297 \mathrm{~K}$. The ${ }^{13} \mathrm{C}$ chemical shifts were measured relative to TMS.

X-ray structure determination. Single crystal data collection was performed at $296 \mathrm{~K}$ on a Bruker Kappa APEXII CCD diffractometer equipped with a four-circle goniometer and $\mathrm{Mo} K_{\alpha}$ graphite mono-chromated radiation source. The refinement and all further calculations were carried out using SHELX-97 [13 ]. PLATON was used for molecular graphics [14]. Crystal data and details of the data collection are summarized in Table 1.

Antimicrobial activities. The antimicrobial activities (average of three measurements) of the free ligand, the silver(I) complex and Amoxil (as a standard drug) were estimated by minimum inhibitory concentrations (MIC; $\mu \mathrm{g} \cdot \mathrm{mL}^{-1}$ ) as described earlier [15]. Standard culture media of bacteria, Esche-

$\mathrm{T} \mathrm{a} \mathrm{b} 1$ e 1

Crystal data and refinement details for compound $\mathbf{1}$

\begin{tabular}{l|c}
\hline Formula & $\mathrm{C}_{6} \mathrm{H}_{15} \mathrm{AgN}_{5} \mathrm{O}_{5.5}$ \\
Formula weight & 353.10 \\
Crystal system & Monoclinic \\
Space group & $C 2$ \\
$a, b, c, \AA ; \beta$, deg. & $12.7060(11), 7.4627(6), 13.0443(13) ; 101.112(6)$ \\
$V, \AA^{3}$ & $1213.69(19)$ \\
$Z$ & 4 \\
$\rho_{\text {calc }}, \mathrm{g} / \mathrm{cm}^{3}$ & 1.932 \\
$\mu\left(\right.$ Mo $\left.K_{\alpha}\right)$, mm & \\
$F(000)$ & 1.686 \\
Crystal size, mm & 708 \\
Temperature, K & $0.34 \times 0.20 \times 0.18$ \\
$\lambda$ Mo $K_{\alpha}, \AA$ & $296(2)$ \\
$2 \theta$ range, deg. & 0.71073 \\
$h, k, l$ limits & $3.18-26.00$ \\
Reflections collected $/$ uniq. & $-15: 15,9: 9,-16: 16$ \\
Reflections observed $[I>2 \sigma(I)]$ & $4219 / 2112[R(\mathrm{int})=0.0309]$ \\
$T_{\text {min }}, T_{\text {max }}$ & 1790 \\
Data / restraints / parameters & $0.598,0.751$ \\
$R_{1}, w R_{2}, S[I>2 \sigma(I)]$ & $2112 / 1 / 168$ \\
Largest diff. peak, hole, e/ $\AA^{3}$ & $0.0359,0.0561,1.044$ \\
Flack parameter & $0.460,-0.636$ \\
& $0.7(3)$ \\
$w=\left[\sigma^{2}\left(F_{0}^{2}\right)+(0.0155 P)^{2}+1.1167 P\right]^{-1}$, where $P=\left(F_{0}^{2}+2 F_{\mathrm{c}}^{2}\right) / 3$. \\
\end{tabular}


${ }^{13} \mathrm{C}$ NMR shifts (ppm) of the free ligand and its Ag(I) complex in DMSO- $d_{6}$

\begin{tabular}{c|c|c|c|c|c|c}
\hline \multicolumn{1}{c|}{ Species } & $\delta \mathrm{C}_{(1)}$ & $\delta \mathrm{C}_{(2)}$ & $\delta \mathrm{C}_{(3)}$ & $\delta \mathrm{C}_{(4)}$ & $\delta \mathrm{C}_{(5)}$ & $\delta \mathrm{C}_{(6)}$ \\
\hline Arginine & 183.41 & 55.81 & 31.87 & 24.74 & & 156.98 \\
$\mathrm{Ag}$-Arginine & 177.81 & 55.57 & 32.94 & 24.11 & 41.34 & 157.39
\end{tabular}

richia coli, (ATCC 13706) and Pseudomonas aeruginosa (MTCC 424), molds i.e., Aspergillus niger (MTCC 1349) and Penicillium citrinum (MTCC 5215) and yeast i.e., Candida albicans (MTCC 183) and Saccharomyces cerevisiae (MTCC 463) were obtained from Qingdao Yijia Huuyi Co. China.

\section{RESULTS AND DISCUSSION}

The title compound, $[\mathrm{Ag}(\arg )]\left(\mathrm{NO}_{3}\right) \cdot 0.5 \mathrm{H}_{2} \mathrm{O}(\mathbf{1})$ was synthesized by reacting silver nitrate and arginine in 1:1 molar ratio in water-acetonitrile solution. The IR spectrum of the complex shows the asymmetric and symmetric stretching vibrations at $1546 \mathrm{~cm}^{-1}$ and $1368 \mathrm{~cm}^{-1}$ respectively. The $\mathrm{N}-\mathrm{H}$ stretching absorption takes place in the region of carboxylate of $3400-3100 \mathrm{~cm}^{-1}$, while the $\mathrm{N}-\mathrm{H}$ bending is observed as a broad peak around $1680 \mathrm{~cm}^{-1}$. An absorption band at $806 \mathrm{~cm}^{-1}$ indicates the presence of $\mathrm{NO}_{3}^{-}$group in the complex.

In the proton NMR spectrum of $\mathbf{1}$, the $\mathrm{N}-\mathrm{H}$ chemical shifts appeared at $7.08 \mathrm{ppm}$ and $9.24 \mathrm{ppm}$. The resonances at $3.24 \mathrm{ppm}, 3.10 \mathrm{ppm}, 2.99 \mathrm{ppm}$ and $1.61 \mathrm{ppm}$ are assigned to the $\mathrm{C}_{2}, \mathrm{C}_{5}, \mathrm{C}_{3}$ and $\mathrm{C}_{4}$ protons respectively. The first two resonances are slightly upfield shifted, compared to that of free ligand at $3.76,3.24$, while the $\mathrm{C}_{3}$ proton resonance is shifted downfield with respect to free ligand at $2.04 \mathrm{ppm}$. The ${ }^{13} \mathrm{C}$ NMR spectrum of the complex displays six resonances as given in Table 2 . The carboxyl resonance appears at the most downfield position. This is about $6 \mathrm{ppm}$ upfield shifted with respect to free ligand resonance, consistent with the coordination of the carboxylate group. The other resonances are only slightly shifted.

Crystal structure description. The molecular structure representation of silver-arginine complex (1), together with the atomic labeling scheme is shown in Fig. 1. Selected bond lengths and bond angles are represented in Table 3. The structure of the complex is polymeric consisting of $[\operatorname{Ag}(\operatorname{arginine})]^{+}$ monomeric units with one water molecules and a nitrate counter ion. In the polymeric complex, each silver(I) ion is bound to one arginine molecule through carboxyl oxygen and to another nitrogen atom of amino group. The $\mathrm{N}-\mathrm{Ag}-\mathrm{O}$ bonding units are repeated as shown in Fig. 2. Arginine ligand with deprotonated carboxyl group binds in a N, O bridging mode. Similar binding modes have been reported in other polymeric silver(I) complexes of amino acids $[2-4,10-12]$. The $\mathrm{O}(1)-\mathrm{Ag}(1)-$ $\mathrm{N}(1)$ bond angle of $168.43(17)^{\circ}$ is somewhat less than that of linear coordination so that the silver(I) ion exhibits distorted linear geometry (Table 3). The $\mathrm{Ag}(1)-\mathrm{O}(1)$ and $\mathrm{Ag}(1)-\mathrm{N}(1)$ distances are $2.138(5) \AA$ and 2.158(7) $\AA$ respectively and are in agreement with those reported for related compounds $[2-4,10-12]$, e.g., $[\mathrm{Ag}(\text { asparagine })]_{n}[2]$. The two C-O bond lengths $(1.225(9) \AA$ and $1.268(8) \AA)$ and the two $\mathrm{C}-\mathrm{C}-\mathrm{O}$ bond angles $\left(115.5(7)^{\circ}\right.$ and $\left.120.4(7)^{\circ}\right)$ of carboxylic group are different indicating a decrease in resonance in $\mathrm{COO}^{-}$group upon coordination. The $\mathrm{Ag}$ - carboxylate plane is nearly planar, with the $\mathrm{Ag}(1)-\mathrm{O}(1)-\mathrm{C}(1)-\mathrm{O}(2)$ torsion angle of $4.8(10)^{\circ}$. The $\mathrm{Ag}-\mathrm{Ag}$ distance of $3.0825(9) \AA$ is below the sum of the van der Walls radii of two silver atoms $(3.44 \AA)$, which is considered to be the upper limit of the distance for viable argentophilic $d^{10}-d^{10}$ interactions $[16,17]$.

Fig. 1. A view of the molecular structure of $\mathbf{1}$ with complete atom labeling scheme. Displacement ellipsoids are drawn at the $50 \%$ probability level

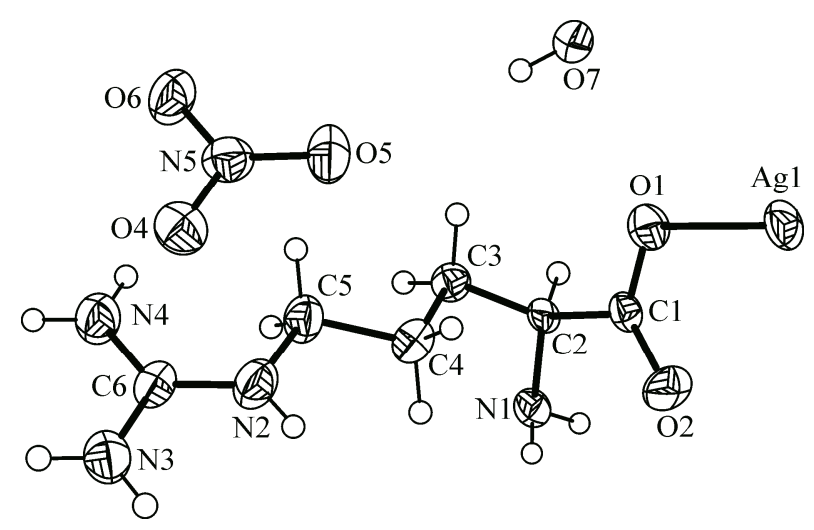


T a b 1 e 3

Selected bond distances $(\AA)$ and bond angles (deg.) for $\mathbf{1}$

\begin{tabular}{c|l}
\hline \multicolumn{3}{c}{ Bond distances } \\
\hline $\mathrm{Ag}(1)-\mathrm{O}(1)$ & $2.138(5)$ \\
$\mathrm{Ag}(1)-\mathrm{N}(1)$ & $2.158(7)$ \\
$\mathrm{Ag}(1)-\mathrm{Ag}(1)$ & $3.0828(12)$ \\
$\mathrm{O}(1)-\mathrm{C}(1)$ & $1.268(8)$ \\
$\mathrm{O}(2)-\mathrm{C}(1)$ & $1.225(9)$ \\
$\mathrm{N}(1)-\mathrm{C}(2)$ & $1.464(9)$ \\
$\mathrm{N}(2)-\mathrm{C}(5)$ & $1.452(10)$ \\
\hline \multicolumn{2}{c}{$\mathrm{Bond}$ angles } \\
\hline $\mathrm{O}(1)-\mathrm{Ag}(1)-\mathrm{N}(1)$ & $168.43(17)$ \\
$\mathrm{O}(1)-\mathrm{Ag}(1)-\mathrm{Ag}(1)$ & $83.90(15)$ \\
$\mathrm{N}(1)-\mathrm{Ag}(1)-\mathrm{Ag}(1)$ & $85.20(19)$ \\
$\mathrm{C}(1)-\mathrm{O}(1)-\mathrm{Ag}(1)$ & $112.8(5)$ \\
$\mathrm{C}(2)-\mathrm{N}(1)-\mathrm{Ag}(1)$ & $117.7(5)$ \\
$\mathrm{O}(1)-\mathrm{C}(1)-\mathrm{O}(2)$ & $124.1(7)$ \\
$\mathrm{O}(4)-\mathrm{N}(5)-\mathrm{O}(5)$ & $120.3(7)$
\end{tabular}

$\mathrm{Tab} 1 \mathrm{e} 4$

Hydrogen bonds in the title complex $(\AA$, deg.)

\begin{tabular}{|c|c|c|c|c|}
\hline Donor- $-\mathrm{H} \cdots$ Acceptor & $\mathrm{D}-\mathrm{H}$ & $\mathrm{H} \cdots \mathrm{A}$ & $\mathrm{D} \cdots \mathrm{A}$ & $\angle \mathrm{D}-\mathrm{H} \cdots \mathrm{A}$ \\
\hline $\mathrm{N} 1-\mathrm{H} 1 \mathrm{~A} \ldots \mathrm{O} 4$ & 0.84 & 2.31 & $3.068(9)$ & 150 \\
\hline N1-H1B...O6 & 0.90 & 2.18 & $3.072(13)$ & 170 \\
\hline $\mathrm{N} 2-\mathrm{H} 2 \mathrm{~A} \ldots \mathrm{O} 3$ & 0.86 & 2.06 & $2.900(9)$ & 165.5 \\
\hline $\mathrm{N} 3-\mathrm{H} 3 \mathrm{C} \ldots \mathrm{O} 5$ & 0.86 & 2.07 & $2.920(12)$ & 170.7 \\
\hline $\mathrm{N} 3-\mathrm{H} 3 \mathrm{D} \ldots \mathrm{O} 4$ & 0.86 & 2.10 & $2.954(9)$ & 169.4 \\
\hline $\mathrm{N} 4-\mathrm{H} 4 \mathrm{C} \ldots \mathrm{O} 2$ & 0.86 & 2.15 & $3.006(9)$ & 172.8 \\
\hline N4-H4D...O3 & 0.86 & 2.09 & $2.949(12)$ & 174.2 \\
\hline $\mathrm{C} 4-\mathrm{H} 4 \mathrm{~B} \ldots \mathrm{O} 5$ & 0.97 & 2.55 & $3.354(8)$ & 140.1 \\
\hline
\end{tabular}

The nitrate ion is planar but exhibits strong hydrogen bonding interactions with the $\mathrm{NH}$ groups of the arginine ligand. Hydrogen bonding interactions take place, involving each of the NH groups and nitrate oxygen atoms. The uncoordinated oxygen atoms of carboxyl group as well as of water molecules are also involved in $\mathrm{H}$ bonding. The details of hydrogen bonding are given in Table 4 .

Antimicrobial activities. The antimicrobial activities (average of three measurements) of the free ligand, the silver(I) complex and Amoxil (a standard drug) estimated by minimum inhibitory concentrations (MIC; $\mu \mathrm{g} \cdot \mathrm{mL}^{-1}$ ) are listed in Table 5. The comercially available antibiotic, Amoxil is highly effective against

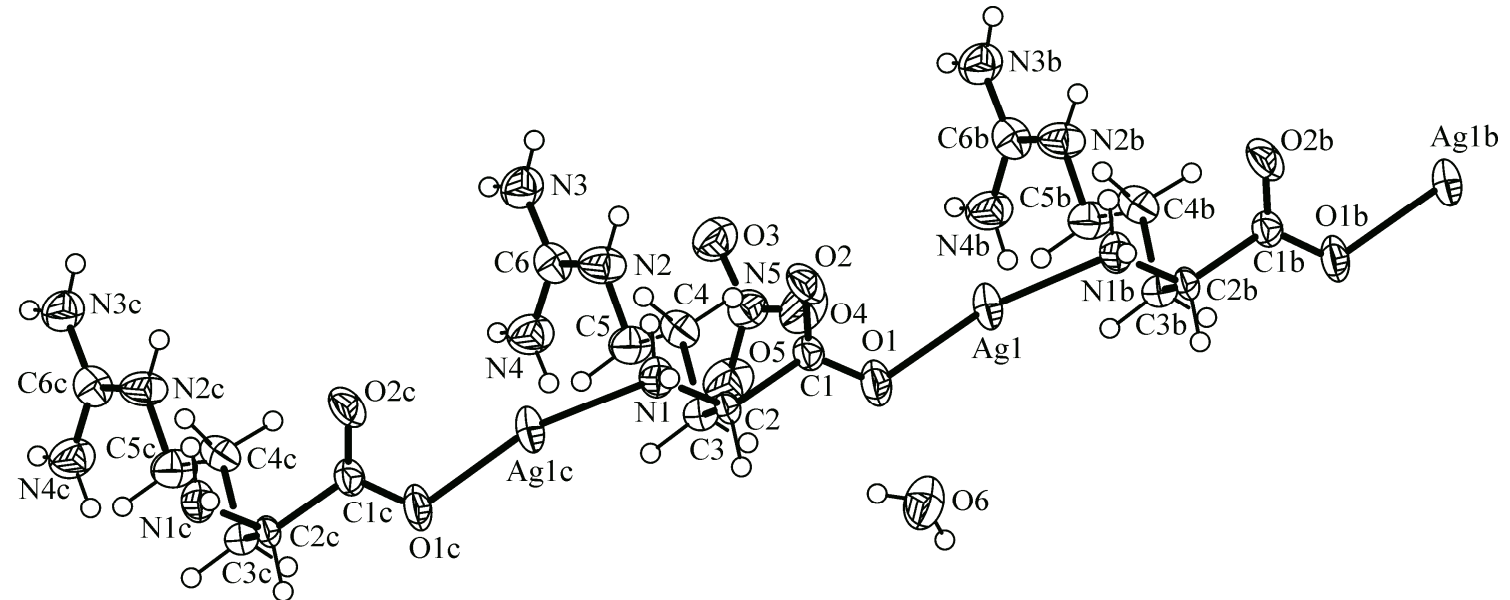

Fig. 2. Formation of a polymeric chain in compound $\mathbf{1}$

$\mathrm{T}$ a b 1 e 5

Antimicrobial activities of the title complex evaluated by the minimum inhibitory concentration $\left(\mathrm{MIC} ; \mu \mathrm{g} \cdot \mathrm{mL}^{-1}\right)$

\begin{tabular}{c|c|c|c|c|r|r}
\hline \multirow{2}{*}{ Species } & \multicolumn{5}{|c}{ Microbial activity (in terms of MIC: $\mu \mathrm{mL}^{-1}$ ) } \\
\cline { 2 - 6 } & $\begin{array}{c}\text { Escherichi. } \\
\text { coli }\end{array}$ & $\begin{array}{c}\text { Pseudomonas } \\
\text { aeruginosa }\end{array}$ & $\begin{array}{c}\text { Aspergillus } \\
\text { niger }\end{array}$ & $\begin{array}{c}\text { Penicillium } \\
\text { citrinum }\end{array}$ & $\begin{array}{c}\text { Candida } \\
\text { albicans }\end{array}$ & $\begin{array}{c}\text { Saccharomyces } \\
\text { cerevisiae }\end{array}$ \\
\hline Amoxil & 8 & 12 & 890 & 870 & 660 & 580 \\
Arginine & 320 & 430 & 600 & 720 & 840 & $>1000$ \\
$\{[$ Ag(arginine $\left.)]\left(\mathrm{NO}_{3}\right) \cdot\left(\mathrm{H}_{2} \mathrm{O}\right)_{0.5}\right\}_{n}$ & 400 & 520 & 580 & $>1000$ & $>1000$ & $>1000$
\end{tabular}


the studied bacteria. However, moderate activity of Amoxil is found for molds (A. niger, P. citrinum) and yeast (C. albicans, S. serevisaiae). It can be seen from Table 5 that the complex 1 showed a remarkable activity against two gram-negative bacteria (E. coli, $P$. aeruginosa). Moderate activity was observed against mold (A. niger, $P$. citrinum). The yeasts (C. albicans, $S$. serevisaiae) and another mold (P. citrinum) did not show significant activity. This activity could be attributed to whether or not the complexes possess the tendency to undergo ligand replacement with the biological molecules such as proteins and DNA [1]. The significant activities of the present complex suggest that silver(I) is labile, and replacement by biological ligands is possible. In most of the cases, the activities of the complex are less than those of free arginine.

The present study describes that silver(I) forms a polymeric complex with arginine, $\{[\mathrm{Ag}(\operatorname{argi}-$ nine) $\left.]\left(\mathrm{NO}_{3}\right)\left(\mathrm{H}_{2} \mathrm{O}\right)_{0.5}\right\}_{n}$, in which arginine ligand coordinates through oxygen and nitrogen atoms to different silver(I) ions. The title complex exhibits significant antibacterial properties.

Crystallographic data for the structure reported in this paper have been deposited with the Cambridge Crystallographic Center under CCDC No. 983599. Copies of the data can be obtained free of charge on application to CCDC, 12 Union Road, Cambridge CB2 1EZ, UK; E-mail: deposit@ccdc.cam.ac.uk].

\section{REFERENCES}

1. Ahmad S., Isab A.A., Ali S., Al-Arfaj A.R. // Polyhedron. - 2006. - 25. - P. 1633 - 1645.

2. Nomiya K., Yokoyama H.J. // J. Chem. Soc., Dalton Trans. - 2002. - P. 2483 - 2490.

3. Kasuga N.C., Takagi Y., Tsuruta S., Kuwana W., Yoshikawa R., Nomiya K. // Inorg. Chim. Acta. - 2011. - 368. - P. $44-48$.

4. Nomiya K., Takahashi S., Noguchi R., Nemoto S., Takayama T., Oda M. // Inorg. Chem. - 2000. - 39. - P. $3301-3311$.

5. Kasuga N.C., Yoshikawa R., Sakai Y., Nomiya K. // Inorg. Chem. - 2012. - 51. - P. 1640 - 1647.

6. Legler A.V., Kazachenko A.S., Kazbanov V.I., Peryanova O.V., Veselov O.F. // Pharmaceut. Chem. J. - 2001. - 35. - P. $501-503$.

7. Nomiya K., Takahashi S., Noguchi R. // J. Chem. Soc., Dalton Trans. - 2000. - P. 4369 - 4373.

8. Nomiya K., Tsuda K., Sudoh T., Oda M. // J. Inorg. Biochem. - 1997. - 68. - P. 39 - 44.

9. Abuskhuna S., Briody J., McCann M., Devereux M., Kavanagh K., Fontecha J.B., McKee V. // Polyhedron. - 2004. - 23. - P. $1249-1255$.

10. Acland C.B., Freeman H.C. // J. Chem. Soc., Chem. Commun. - 1971. - P. 1016 - 1017.

11. Demaret P.A., Abraham F. // Acta Crystallogr. - 1987. - C43. - P. 1519 - 1521.

12. Wang L., Pei Y. // Acta Crystallogr. - 2006. - E62. - P. m1487-m1488.

13. Sheldrick G.M. // Acta Crystallogr. - 2008. - A64. - P. $112-122$.

14. Spek A.L. // Acta Crystallogr. - 2009. - D65. - P. 148 - 155.

15. Malik M.R., Vasylyeva V., Merz K., Metzler-Nolte N., Saleem M., Ali S., Isab A.A., Munawar K.S., Ahmad S. // Inorg. Chim. Acta. - 2011. - 376. - P. $207-211$.

16. Pyykko P. // Chem. Rev. - 1997. - 97. - P. 597 - 636.

17. Koskinen L., Jaaskelainen S., Oresmaa L., Haukka M. // CrystEngComm. - 2012. - 14. - P. 3509 - 3514. 